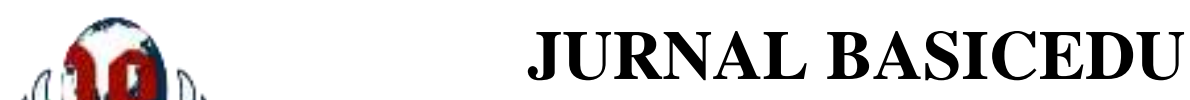

Volume 5 Nomor 5 Tahun 2021 Halaman 4340 - 4351

Research \& Learning in Elementary Education

https://jbasic.org/index.php/basicedu

PAHLATAN

\title{
Pengembangan Buku Ajar Digital Bahasa Indonesia Berbasis HOTS untuk Meningkatkan Kemampuan Pemecahan Masalah Mahasiswa STKIP Muhammadiyahmuara Bungo
}

\author{
Reni Guswita ${ }^{\bowtie}$ \\ STKIP Muhamamdiyah Muara Bungo, Indonesia \\ E-mail: guswitareni@gmail.com
}

\begin{abstract}
Abstrak
Tantangan pendidikan di era revolusi industri 4.0 yang bertepatan dengan masa Pandemi Covid 19 ini menuntut tersedianya sumber daya manusia yang menguasai ilmu pengetahuan, teknologi, dan seni (IPTEKS). Pembelajaran diberbagai tingkat pendidikan terpaksa harus menerapkan sistem daring. Salah satuupaya mendukung pembelajaran daring yaitu dengan mengembangkan buku ajar digital Bahasa Indonesia berbasis Higher Order Thinking Skills (HOTS). Penelitian ini bertujuan untuk mengoptimalkan proses dan tujuan pembelajaran dan menghasilkan buku ajar digital yang menunjang pembelajaran daring. Penelitian ini merupakan penelitian Researchand Development dengan model 4-D. Keempat tahap itu adalah pendefinisian (define), perancangan (design), pengembangan (develop), dan penyebaran (disseminate). Target penelitian adalah menghasilkan buku ajar digital yang valid, praktis, dan efektif. Subjek penelitian ini, yaitu mahasiswa PGSD 1D Semester Ganjil. Instrumen penelitian yang digunakan, yaitu instrumen validitas produk, instrumen keperaktisan produk, dan instrumen keefektifan produk. Hasil penelitian menunjukkan bahwa 1) Buku ajar digital Bahasa Indonesia berbasis Higher Order Thinking Skills (HOTS) dapat meningkatkan kemampuan pemecahan masalah mahasiswa dalam pembelajaran. 2) Buku ajar digital Bahasa Indonesia berbasis Higher Order Thinking Skills (HOTS) valid dan layak digunakan. Hal ini ditunjukkan dengan hasil analisis validasi ahli materi pembelajaran, ahli media pembelajaran dan mahasiswa menunjukkan kategori sangat baik.
\end{abstract}

Kata Kunci: Bahasa Indonesia, HOTS, kemampuan pemecahan masalah

\begin{abstract}
The challenges of education in the era of the industrial revolution 4.0, which coincides with the Covid-19 pandemic, demands the availability of human resources who master science, technology, and art (IPTEKS). Learning at various levels of education is forced to implement an online system. One of the efforts to support online learning is by developing Indonesian digital textbooks based on Higher Order Thinking Skills (HOTS). This research aims to optimize the learning process and objectives and produce digital textbooks that support online learning. This is a Research and Development with a 4-D model. The four stages are defining, designing, developing, and disseminating. The research target is to produce valid, practical, and effective digital textbooks. The subject of this research was the students of PGSD 1D Odd Semester. The research instruments used are product validity instruments, product practicality instruments, and product effectiveness instruments. The results showed that 1) Indonesian digital textbooks based on Higher Order Thinking Skills (HOTS) can improve students' problem-solving skill in learning. 2) Indonesian digital textbooks based on Higher Order Thinking Skills (HOTS) are valid and suitable for use. This is indicated by the results of the validation analysis of learning material experts, learning media experts, and students showing a very good category.
\end{abstract}

Keywords: Bahasa Indonesia, HOTS, problem-solving skill

Copyright (c) 2021 Reni Guswita

Corresponding author :

Email : guswitareni@gmail.com

DOI : https://doi.org/10.31004/basicedu.v5i5.1496

ISSN 2580-3735 (Media Cetak)

ISSN 2580-1147 (Media Online)

Jurnal Basicedu Vol 5 No 5 Tahun 2021

p-ISSN 2580-3735 e-ISSN 2580-1147 
4341 Pengembangan Buku Ajar Digital Bahasa Indonesia Berbasis HOTS untuk Meningkatkan Kemampuan Pemecahan Masalah Mahasiswa STKIP Muhammadiyahmuara Bungo - Reni Guswita

DOI: https://doi.org/10.31004/basicedu.v5i5.1496

\section{PENDAHULUAN}

Tantangan perkembangan pendidikan semakin menuntut tersedianya sumber daya manusia yang menguasai ilmu pengetahuan, teknologi, dan seni (IPTEKS). Apalagi di masa Pandemi Covid-19 sekarang ini, hampir seluruh sektor kehidupan lumpuh tidak terkecuali di bidang pendidikan. Dunia pendidikan banyak mengalami perubahan. Pendidik yang sebelumnya acuh tak acuh dengan pembelajaran berbasis teknologi, kini dipaksa untuk mau belajar. Begitu juga di STKIP-MB, awalnya masih belum sepenuhnya melakukan pembelajaran bersistem daring, kini harus menerapkan pembelajaran daring untuk semua mata kuliah.

STKIP-MB sebenarnya telah memfasilitasi para dosen untuk mengadakan e-learning melalui https://elearning.stkip-mmb.ac.id. Tidak terkecuali pada Mata Kuliah Bahasa Indonesia. Namun, pembelajaran daring yang dilakukan belum optimal. Terdapat kendala-kendala yang dialami oleh dosen dan mahasiswa dalam proses perkuliahan. Berdasarkan hasil observasi yang dilakukan pada tanggal 29 September 2020, ditemukan fakta bahwa sumber belajar yang digunakan sulit dijangkau karena masih dalam bentuk cetak. Mahasiswa dituntut untuk ke perpustakaan atau ke toko buku untuk mendapatkan buku referensi. Hal ini bertentangan dengan anjuran pemerintah untuk tetap di rumah 'stayathome'. Selain itu, ketersediaan buku referensi perkuliahan Bahasa Indonesia di perpustakaan juga masih terbatas dan kurang variatif. Kondisi ini menyebabkan tidak semua mahasiswa mendapat kesempatan meminjam buku tersebut. Apalagi, beberapa mahasiswa berdomisili jauh dari lokasi kampus. Akibatnya, tidak semua mahasiswa memiliki sumber belajar yang memadai. Mahasiswa akhirnya belajar dan membuat tugas menggunakan sumber yang kurang ilmiah seperti blogspot. Fakta ini juga didukung dari hasil wawancara dengan beberapa mahasiswa yang dilakukan bahwa tugas perkuliahan diadopsi dari blogspot.

Buku ajar dapat mendorong peserta didik untuk meningkatkan pengetahuannya secara luas dan tercapai apa yang mereka cita-citakan, serta dengan adanya buku teks maka mahasiswa mampu menggali seluruh informasi yang ada dalam buku tersebut dengan baik(Suwartini, 2018). Lebih lanjut lagi (Pinis \& Darmayanti, 2019)mengemukakan bahwa Buku ajar merupakan panduan mahasiswa dalam kegiatan pembelajaran yang memuat materi pelajaran, kegiatan penyelidikan berdasarkan konsep informasi dan lain-lain. Buku ajar juga menjadi bacaan bagi siswa ketika belajar di sekolah maupun di rumah. Dalam (Sugiarto et al., 2018). Buku ajar Bahasa Indonesia pada umumnya hanya membahas teori umum kebahasaan saja. Materi yang disajikan belum mengarahkan pada pengembangan kreativitas, inovasi, kecakapan berkomunikasi, dan kekuatan berpikir tinggi atau Higher Order Thinking Skills (HOTS). HOTS merupakan proses berpikir kompleks dalam menguraikan materi, membuat kesimpulan, membangun representasi, menganalisis, dan membangun hubungan dengan melibatkan aktivitasmental yang paling dasar (Saraswati \& Agustika, 2020). Kemampuan berpikir tinggi tersebut sangat dibutuhkan mahasiswa dalam mengatasi persoalan yang dihadapi kedepannya (Mardiana, 2017).

Sejauh pengamatan peneliti, pengembangan buku ajar digital Bahasa Indonesia untuk Perguruan Tinggi berbasis HOTS belum pernah dilakukan. Oleh karena itu, penelitian ini sangat menarik dan penting untuk dilakukan. Penelitian ini juga menawarkan manfaat yang luar biasa karena buku ini dapat digunakan sebagai buku pegangan bagi dosen dan mahasiswa untuk menumbuhkan kreativitas dan daya pikir kritis dalam memahami teks-teks bahasa. (Sari et al., 2019) mengkategorikan HOTS sebagai berikut: HOTS sebagai transfer (HOTS as transfer), HOTS sebagai berpikir kritis (HOTS as critical Thinking), HOTS sebagai pemecahan masalah (HOTS as problem solving). Beberapa permasalahan dalam perkuliahan Bahasa Indonesia sistem daring ini perlu mendapat perhatian dari semua pihak. Oleh karena itu, perlu dikembangkan buku ajar yang inovatif untuk menunjang pembelajaran virtual. Buku yang dikembangkan hendaknya menekankan pada pengembangan HOTS mahasiswa. Jadi, penelitian ini berfokus pada bagaimana pengembangan buku ajar digital berbasis HOTS untuk meningkatkan kemampuan pemecahan masalah Mahasiswa STKIP-MB? Tujuan penelitian ini yaitu mengembangkan bahan ajar digital Bahasa Indonesia berbasis HOTS untuk meningkatkan kemampuan pemecahan masalah mahasiswa STKIP Muhammadiyah Muara Bungo. 
4342 Pengembangan Buku Ajar Digital Bahasa Indonesia Berbasis HOTS untuk Meningkatkan Kemampuan Pemecahan Masalah Mahasiswa STKIP Muhammadiyahmuara Bungo - Reni Guswita

DOI: https://doi.org/10.31004/basicedu.v5i5.1496

Pengajaran Bahasa Indonesia di perguruan tinggi menempati posisi sebagai mata kuliah umum (Rabiah, 2014). Pada hakikatnya, belajar bahasa merupakan belajar berkomunikasi. Hal ini sejalan dengan pendapat (Sitepu \& Rita, 2017) yang menyatakan bahwa pembelajaran Bahasa Indonesia diarahkan untuk meningkatkan kemampuan berkomunikasi dengan baik secara lisan maupun tertulis. Dalam pembelajaran bahasa, terdapat empat aspek yang harus dikuasai oleh mahasiswa, yaitu membaca, berbicara, menyimak, dan mendengarkan (Guswita, 2020). Keterampilan berbahasa ini tidak hadir dengan sendirinya, tetapi dengan latihan yang terus menerus dan sistematis.

Higher Order Thinking Skill (HOTS) merupakan keterampilan berpikir tingkat tinggi yang menuntut pemikiran secara kritis, kreatif, analitis, terhadap informasi, dan data dalam memecahkan permasalahan (Barratt-Pugh \& Rohl, 2016). Berfikir tingkat tinggi merupakan jenis pemikiran yang mencoba mengeksplorasi pertanyaan-pertanyaan mengenai pengetahuan yang ada terkait isu-isuyang tidak didefinisikan dengan jelas dan tidak memiliki jawaban yang pasti( D e s a in e t a 1., 2019 ).

Pengembangan keterampilan kritis menuntut latihan menemukan pola, menyusun penjelasan, membuat hipotesis, melakukan generalisasi, dan mendokumentasikan temuan-temuan dengan bukti (Eggen Paul, 2012). Hal ini menunjukkan bahwa pembelajaran berbasis HOTS dapat memicu mahasiswa untuk berfikir tingkat tinggi (Arnidah \& Anwar, 2020). Mahasiswa dituntut untuk aktif mengamati, menanya, menalar, mencoba, dan mengkomunikasikan temuan pembelajaran.

Pengembangan keterampilan berpikir tingkat tinggi memiliki sebelas strategi, yaitu (1) apa perbedaannya, (2) apa persamaannya, (3) membandingkan, (4) memilah, (5) Apa penyebabnya, (6) merangkum, (7) membuat kategori, (8) menyelesaikan masalah, (9) curah pendapat, (10) mempertimbangkan berbagai macam pilihan, dan (11) bahasa yang digunakan meningkatkan cara berpikir (Merril, 2001). Pengembangan pembelajaran yang memperhatikan keterampilan berfikir tingkat tinggi ini harus memperhatikan tahapan berfikir sesuai dengan Taksonomi Bloom (Dinni, 2018).

Keberhasilan proses pembelajaran ditentukan oleh banyak faktor. Salah satu faktor yang berperan penting yaitu buku ajar. Untuk menunjang pembelajaran daring di masa Pandemi Covid-19 ini, dibutuhkan bahan ajar digital. Buku ajar digital dirancang dengan konsep buku digital yang komunikatif dan memudahkan mahasiswa memilih bagian-bagian pokok bahasan yang ingin diakses (Fuada, 2018). Buku ajar digital juga dilengkapi dengan latihan soal secara online akhirnya menjadi suatu pengembangan bahan pembelajaran yang disajikan secara digital (Bakri et al., 2016). Hal ini berkaitan dengan tuntutan akan buku ajar yang lebih inovatif. Buku digital memiliki perwajahan seperti sebuah buku (dengan lembaran yang dapat dibolak-balik), tetapi dilengkapi dengan animasi dan icon yang menarik. Pemilihan setiap unsur layout buku digital, baik warna, font, gambar animasi, serta komposisinya mempertimbangkan aspek kelayakan, estetika, serta fungsional yang memberi kemudahan pembaca dalam menggunakannya.

(Indariani et al., 2019) menjelaskan keunggulan bahan ajar digital dapat mendukung pembelajaran jarak jauh/ distance learning (DL). Dalam sistem pembelajaran di perguruan tinggi, distance learning menjadi mode pembelajaran yang relevan dan banyak dituntut selama dekade terakhir. Lebih lanjut (Faisal et al., 2020) menjelaskan bahwa membuat bahan ajar memiliki kontribusi yang sangat besar bagi keberhasilan proses pembelajaran yang kita lakukan

Pengembangan buku ajar digital perlu memperhatikan aspek-aspek tertentu agar buku menjadi efektif digunakan, diantaranya: 1) buku yang dikembangkan harus mampu mengembangkan kemampuan bernalar, 2) buku yang dikembangkan harus mampu memancing analisis dan evaluasi terhadap permasalahan yang diberikan, 3) buku yang dikembangkan harus mampu merangsang proses berpikir mahasiswa untuk kreatif dan inovatif terhadap tantangan yang diberikan (Lastuti, 2018)

Pengembangan buku ajar digital ini akan dirancang sesuai dengan capaian mata kuliah dan silabus perkuliahan. Adapun penjelasan dari tahapan-tahapan model desain pembelajaran di atas menurut Thiagarajan (1974) dalam (Indra Kartika Sari, 2021) adalah sebagai berikut: 
4343 Pengembangan Buku Ajar Digital Bahasa Indonesia Berbasis HOTS untuk Meningkatkan Kemampuan Pemecahan Masalah Mahasiswa STKIP Muhammadiyahmuara Bungo - Reni Guswita

DOI: https://doi.org/10.31004/basicedu.v5i5.1496

\section{a. Tahap Pendefinisian (Define)}

Tahapan ini memiliki tujuan untuk menetapkan dan mendefinisikan syarat-syarat pembelajaran. Pada tahapan ini dilakukan analisis tujuan dan batasan materi ajar yang perangkatnya akan dikembangkan. Tahap ini terdiri atas lima langkah, yaitu: 1) Analisis Awal-Akhir, 2) Analisis mahasiswa, 3) Analisis Tugas, 4) Analisis Konsep, 5) Spesifikasi Tujuan Pembelajaran.

b. Tahap Perancangan (Design)

Tahap ini bertujuan untuk menghasilkan rancangan awal buku ajar digital Bahasa Indonesia yang meliputi: penetapan capaian mata kuliah, penyusunan materi, penyusunan tes, pemilihan format dan layout.

c. Tahap Pengembangan (Develop)

Tahap pengembangan bertujuan menghasilkan buku ajar digital yang layak. Buku akan diuji validitas, praktikalitas, dan efektivitasnya. Buku akan direvisi sesuai masukan para ahli dan hasil diuji coba di kelas yang menjadi subjek penelitian.

d. Tahap penyebaran (Dessiminate)

Tahap ini merupakan tahap penyebaran atau penggunaan buku ajar digital yang telah valid, praktif, dan efektif. Buku akan digunakan dalam perkuliahan Bahasa Indonesia

\section{METODE}

Penelitian ini mengunakan desain penelitian Researchand Development dengan model 4-D. Model pengembangan menurut (Thiagarajan, 2014) terdiri atas empat tahap, sehingga disebut "Four-DModel". Keempat tahap itu adalah pendefinisian (define), perancangan (design), pengembangan (develop), dan penyebaran (disseminate).

Langkah-langkah penelitian pengembangan mengacu pada desain penelitian 4D. Pertama, tahap pendefinisian (Define), yaitu tahap menetapkan dan mendefinisikan syarat-syarat pembelajaran. Pada tahapan ini dilakukan analisis tujuan dan batasan materi ajar yang perangkatnya akan dikembangkan.Tahap ini terdiri atas lima langkah, yaitu: 1) analisis awal-akhir, 2) analisis mahasiswa, 3) analisis tugas, 4) analisis konsep, 5) spesifikasi tujuan pembelajaran. Kedua, tahap perancangan (Design), yaitu tahap yang bertujuan untuk menghasilkan rancangan awal buku ajar digital Bahasa Indonesia yang meliputi: penetapan capaian mata kuliah, penyusunan materi, penyusunan tes, pemilihan format dan layout. Ketiga, tahap pengembangan (Develop), yaitu tahap menghasilkan buku ajar digital yang layak. Buku akan diuji validitas, praktikalitas, dan efektivitasnya. Buku akan direvisi sesuai masukan para ahli dan hasil diuji coba di kelas yang menjadi subjek penelitian. Keempat, tahap penyebaran (Dessiminate), yaitu tahap penyebaran atau penggunaan buku ajar digital yang telah valid, praktif, dan efektif. Buku akan digunakan dalam perkuliahan Bahasa Indonesia (Zahroh \& Sudira, 2014).

Subjek uji coba penelitian ini seluruh mahasiswa PGSD 1D STKIP Muhammadiyah Muara Bungo tahun 2021 Semester Ganjil. Adapun lokasi penelitian yaitu di STKIP Muhammadiyah Muara Bungo. Dalam mengumpulkan data penelitian ini, peneliti menggunakan instrumen penelitian. Instrumen yang dimaksud adalah suatu alat untuk menjaring data atau alat pengukuran untuk menghasilkan informasi yang objektif dan dapat diberikan dalam bentuk kata-kata atau angka-angka (Borich, 2014). Instrumen yang dikembangkan dalam penelitian ini meliputi:

1. Instrumen validitas produk

Adapun instrumen validasi yang digunakan yaitu (1) lembar validasi materi buku ajar digital, (2) Angket respon dosen terhadap buku ajar digital, (3) Angket respon mahasiswa terhadap buku ajar digital. Lembar validasi ini digunakan untuk mengetahui kualitas buku ajar digital yang dikembangkan.

2. Instrumen keperaktisan produk

a. Lembar Keterlaksaan Penggunaan materi ajar

b. Lembar Aktivitas Mahasiswa 
4344 Pengembangan Buku Ajar Digital Bahasa Indonesia Berbasis HOTS untuk Meningkatkan Kemampuan Pemecahan Masalah Mahasiswa STKIP Muhammadiyahmuara Bungo - Reni Guswita

DOI: https://doi.org/10.31004/basicedu.v5i5.1496

3. Instrumen keefektifan produk

a. Lembar hasil belajar mahasiswa

b. Lembar penilaian sikap untuk mengukur kemampuan sikap (keterampilan berpikir kritis) mahasiswa

c. Lembar penilaian projek untuk mengukur aspek keterampilan mahasiswa

Buku ajar digital yang dikembangkan telaah oleh pakar untuk dinilai. Data hasil penilaian dianalisis secara deskriptif kualitatif. Dalam penelitian ini passing grade adalah skor rerata $(\mathrm{P})$ dari hasil penilaian para pakar, kemudian disesuaikan dengan kriteria penilaian perangkat menurut Borich (2014:124) sebagai berikut:

Tabel 1

Kriteria Pengkategorian Materi Ajar

\begin{tabular}{cc}
\hline Interval Skor & Kategori Penilaian \\
\hline $4 \leq \mathrm{P}$ & Sangat Layak/Valid \\
\hline $3 \leq \mathrm{P}$ & Layak/Valid \\
\hline $2 \leq \mathrm{P}$ & Sedang \\
\hline $1 \leq \mathrm{P}$ & Kurang \\
\hline
\end{tabular}

Data hasil belajar dianalisis dengan menggunakan deskriptif kuantitatif, yaitu menggunakan tingkat ketuntasan individual dan klasikal yang dinyatakan dengan presentase. Analisis hasil belajar pengetahuan dengan menggunakan deskriptif kuantitatif, yaitu menggunakan tingkat ketuntasan individual dan klasikal yang dinyatakan dengan presentase. Persentase ketuntasan individual dan ketuntasan klasikal diperoleh dari rumus berikut:

$\mathrm{P}$ individual $=[\underline{\mathrm{Jumlah} \text { skor yang Diperoleh }}] \times 100 \%$

Skor maksimum

Berdasarkan ketentuan kriteria ketuntasan minimal (KKM), seorang mahasiswa dinyatakan tuntas apabila persentase (p) individual yang dicapai $\geq 75$ dan kriteria ketuntasan klasikal $80 \%$. Selanjutnya data hasil belajar pengetahuan pretest dan postest dianalisis dengan statistic inferensial menggunakan uji $\mathrm{T}$ dua sampel berpasangan dengan syarat data homogeny. Analisis hasil belajar dilakukan untuk mengetahui ada atau tidak ada perbedaan hasil belajar sebelum (pretest) dan sesudah perlakuan (posttest)

\section{HASIL DAN PEMBAHASAN}

\section{Hasil Analisis Tahap Pendefinisian}

Tahap define merupakan langkah paling awal yang dilakukan dalam penelitian ini. Pada tahap ini dilakukan analisis kurikulum, analisis Mahasiswa dan analisis konsep. Berikut ini akan disajikan rincian mengenai masing-masing hasil analisis tersebut.

\section{a. Hasil AnalisisKurikulum}

Analisis ini memberikan informasi mengenai gambaran kompetensi yang harus dikuasai Mahasiswa setelah pembelajaran. Pada analisis ini dilakukan analisis terhadap standar kompetensi lulusan, mencakup kompetensi sikap, pengetahuan, dan keterampilan. Komponen isi, komponen metode dan alat evaluasi.

\section{Tabel 2}

Hasil Analisis Kurikulum

\section{KomponenKurikulum}

\section{Tujuan}

Tujuan Kurikulum terdiri dari:

1. Kompetensi sikap

- Menginternalisasi nilai, norma, dan etika akademik

- Menunjukkan sikap bertanggung jawab atas pekerjaan di bidang keahliannya secara mandiri

\section{Hasil AnalisisTujuan}

Tujuan kurikulum untuk meningkatkan kompetensi sikap, pengetahuan, dan keterampilan mahasiswa. Namun, pembelajaran di masa pandemi ini belum sepenuhnya menunjang tujuan pembelajaran yang dituntut oleh kurikulum. Hal ini disebabkan karena keterbatasan ruang gerak pembelajaran daring dan belum tersedianya sumber belajar yang menunjang 
4345 Pengembangan Buku Ajar Digital Bahasa Indonesia Berbasis HOTS untuk Meningkatkan Kemampuan Pemecahan Masalah Mahasiswa STKIP Muhammadiyahmuara Bungo - Reni Guswita DOI: https://doi.org/10.31004/basicedu.v5i5.1496

2. Kompetensi pengetahuan

- $\quad$ Menguasai konsep dan prinsip penulisan ilmiah

3. Kompetensi keterampilan

- Mampu membuat karangan ilmiah dalam berbagai bentuk (makalah, tugas, tugas akhir, skripsi)

\section{Isi}

KomponenIsi dari kurikulumterdiri dari:

1. Capaian Pembelajaran, yaitu mahasiswa memahami proses penalaran ilmiah, khususnya dalam mendasari pemilihan diksi yang tepat, pembuatan kalimat efektif, pembuatan paragraf, serta perencanaan karangan untuk menghasilkan karya ilmiah (makalah, tugas akhir, dan skripsi) dengan baik dan benar.

2. Kompetensi dasar (KD) merupakan kompetensi yang harus dipelajari mahasiswa untuk mata pelajaran.

3. Materi pelajaran yang digunakan adalah Sejarah dan Perkembangan Bahasa Indonesia, Ragam Bahasa, Kaidah Ejaan PUEBI, Penggunaan Diksi, Kalimat Efektif, Paragraf, Kutipan dan Daftar Pustaka, Karya Tulis Ilmiah.

\section{Metode}

Model pembelajaran yang sesuai dengan tujuan kurikulum adalah model-model pembelajaran dengan pendekatan saintifik. Model pembelajaran ini dapat mendorong Mahasiswa menjadi aktif dalam pembelajaran sehingga pembelajaran menjadi student centered. pembelajaran daring berupa buku digital. Dengan adanya inovasi berupa buku ajar digital Bahasa Indonesia diharapkan dapat mengoptimalkan tujuan pembelajaran Bahasa Indonesia pada mahasiswa.

\section{Hasil Analisis Isi}

Capaian pembelajaran Mata kuliah Bahasa Indonesia pada akhirnya mahasiswa mampu menggunakan Bahasa Indonesia dengan baik dan benar secara tertulis maupun lisan, serta dapat menyusun tugas-tugas perkuliahan dengan mengikuti kaidah tata bahasa yang baik. Materi pembelajaran yang disajikan dalam perkuliahan telah tepat menunjang tujuan pembelajaran, tetapi belum ditunjang dengan ketersediaan sumber belajar yang tepat untuk pembelajaran daring.
Hasil Analisis Metode

Model pembelajaran yang diterapkan sebelumnya masih belum memenuhi harapan kurikulum. Pembelajaran yang diterapkan dosen di kelas dalam menyampaikan materi sudah student centered oriented, tetapi belum optimal. Oleh karena itu diperlukan model pembelajaran yang sesuai dengan pendekatan saintifik untuk diterapkan guru di kelas. Salah satu model yang dianggap sesuai adalah model problem based learning. Buku ajar digital ini dapat merangsang tumbuhnya keterampilan berpikir kritis dan mendorong Mahasiswa menjadi aktif dalam pembelajaran dan menemukan konsep melalui pemecahan masalah.

\section{Evaluasi}

Evaluasi atau penilaian yang digunakan untuk mengukur kompetensi Mahasiswa sesuai tujuan kurikulum terdiri dari Penilaian Kompetensi Pengetahuan melalui tes tertulis. Penilaian Kompetensi Sikap dilakukan dengan menggunakan lembar observasi. Penilaian Kompetensi Keterampilan dengan Penilaian kinerja menggunakan lembar observasi.

\section{Hasil Analisis Evaluasi}

Evaluasi atau Penilaian yang dilakukan sebelumnya masih kurang tepat. Hal ini terlihat dari bentuk penilaian yang dilakukan dosen untuk mengukur kompetensi Mahasiswa. Penilaian yang dilakukan dosen masih terfokus kepada penilaian pengetahuan Mahasiswa saja. Penilaian untuk sikap dan keterampilan dilakukan secara umum atau subjektif saja. Hal ini tidak sesuai dengan penilaian yang diharapkan dalam kurikulum.

Pengembangan buku ajar digital ini berpedoman pada capaian pembelajaran mata kuliah (CPMK). Sesuai standar isi matakuliah Bahasa Indonesia, CPMK Bahasa Indonesia memuat tiga aspek, yaitu aspek sikap, pengetahuan, dan keterampilan, seperti penjabaran berikut. 
Berdasarkan CPMK tersebut, diperoleh gambaran tentang keterampilan yang harus dimiliki oleh mahasiswa, yaitu memiliki kemampuan bernalar, berpikir secara kritis, dan menghasilkan karya ilmiah. Hal tersebut dapat tercapai jika Mahasiswa dilatih untuk menerapkan kompetensi yang diharapkan tersebut. Dengan adanya pengembangan buku ajar digital Bahasa Indonesia berbasis HOTS ini diharapkan mampu merangsang tumbuhnya keterampilan berpikir kritis dan meningkatkan kemampuan pemecahan masalah dalam diri Mahasiswa.

\section{b. AnalisisMahasiswa}

Analisis Mahasiswa dapat dilakukan dengan menggunakan AUM PTSDL (Alat Ungkap Masalah) yang merupakan sebuah instrumen standar yang dapat digunakan dalam rangka memahami dan memperkirakan masalah-masalah yang dihadapi Mahasiswa (Prayitno, 2004). Hasil analisis Mahasiswa menggunakan metode ini dapat dilihat pada Tabel 7.

Tabel 3

AnalisisMahasiswaBerdasarkanAlatUngkapMasalah.

\begin{tabular}{cl}
\hline $\begin{array}{c}\text { Komponen Alat } \\
\text { Ungkap Masalah }\end{array}$ & \multicolumn{1}{c}{ Analisis Mahasiswa } \\
\hline $\begin{array}{c}\text { Persyaratan } \\
\text { Penguasaan Materi } \\
\text { (P) }\end{array}$ & $\begin{array}{l}\text { Secara umum tingkat penguasaan materi awal sebagai prasyarat materi selanjutnya } \\
\text { sudah cukup baik. Namun, masih perlu adanya peningkatan pemahaman yang lebih } \\
\text { komprehensif. Penguasan materi awal yang baik dapat menjadi bekal dalam } \\
\text { memahami materi selanjutnya sehingga Mahasiswa semakin tertarik dan merasa } \\
\text { senang serta melahirkan semangat baru dalam proses pembelajaran selanjutnya. }\end{array}$ \\
\hline Keterampilan & $\begin{array}{l}\text { Berdasarkan aspek keterampilan belajar, rata-rata Mahasiswa sudah cukup terampil } \\
\text { dalam mengikuti aktivitas pembelajaran, tetapi dalam hal penemuan konsep dan }\end{array}$ \\
Belajar (T) & $\begin{array}{l}\text { aplikasinya dalam pemecahan masalah masih perlu adanya bimbingan dan arahan } \\
\text { sehingga mengantarkan Mahasiswa untuk mandiri. }\end{array}$ \\
\hline Sarana dan & $\begin{array}{l}\text { Sumber belajar yang digunakan sudah cukup banyak di perpustakaan STKIP-MB. } \\
\text { Pamun, sumber ajar digital belum ada untuk menunjang pembelajaran daring dan }\end{array}$ \\
& $\begin{array}{l}\text { sumber belajar cetak yang ada belum berbasis HOTS. Jadi, masih perlu } \\
\text { dikembangkan guna menunjang keterlaksanaan pembelajaran daring. }\end{array}$ \\
\hline Diri Pribadi (D) & $\begin{array}{l}\text { Mahasiswa PGSD semester 1 Tahun 2021 memilikiusia rata-rata 17-18 tahun. } \\
\text { Menurut teori perkembangan kognitif piaget, mereka berada pada tahap operasional } \\
\text { formal atau mereka sudah mampu berfikir secara abstrak, artinya Mahasiswa akan }\end{array}$ \\
& $\begin{array}{l}\text { mudah menyelesaikan soal-soal yang membutuhkan analisis data yang cermat dan } \\
\text { imajinasi yang tinggi. Dengan demikian, Mahasiswa sudah mampu menyelesaikan } \\
\text { masalah dengan cara yang lebih baik. }\end{array}$ \\
\hline Lingkungan Sosio- & $\begin{array}{l}\text { Iklim pembelajaran yang dikembangkan dosen sudah memberikan ruang bagi } \\
\text { Mahasiswa untuk membangun hubungan sosial yang efektif melalui aktivitas } \\
\text { Emosional (L) }\end{array}$ \\
& $\begin{array}{l}\text { diskusi, tanya jawab, dan presentasi. Namun, dalam implementasinya masih sangat } \\
\text { dalam proses pembelajaran yang efektif. }\end{array}$ \\
\hline
\end{tabular}

\section{c. Analisis Materi}

Analisis materi merupakan identifikasi materi-materi utama yang akan diajarkan dan menyusunnya secara sistematis serta mencari relevansi konsep yang dipelajari dengan realita dalam kehidupan sehari-hari. Analisis ini ditujukan untuk mengidentifikasi, merinci, dan menyusun secara sistematis prinsip utama dari materi pembelajaran Bahasa Indonesia di Perguruan Tinggi. Adapun cakupan materi pembelajaran Bahasa Indonesia berdasarkan capaian pembelajaran matakuliah sebagai berikut: 1) Sejarah dan Perkembangan Bahasa Indonesia, 2) Ragam Bahasa, 3) Kaidah Ejaan PUEBI, 4) Penggunaan Diksi, 5) Kalimat Efektif, 6) Paragraf, 7) Kutipan dan Daftar Pustaka, 8) Karya Tulis Ilmiah 
4347 Pengembangan Buku Ajar Digital Bahasa Indonesia Berbasis HOTS untuk Meningkatkan Kemampuan Pemecahan Masalah Mahasiswa STKIP Muhammadiyahmuara Bungo - Reni Guswita

DOI: https://doi.org/10.31004/basicedu.v5i5.1496

\section{Hasil Analisis Tahap Perancangan}

Berdasarkan hasil dari tahap define, maka lahirlah design instruksional produk yang akan dikembangkan yaitu bahan ajar digital Bahasa Indonesia berbasis HOTS. Berdasarkan analisis kurikulum, analisis Mahasiswa, dan analisis materi, maka dilakukan perancangan bahan ajar digital Bahasa Indonesia berbasis HOTS. Bahan ajar berbasis HOTS yang dikembangkan bertujuan untuk meningkatkan kemampuan pemecahan masalah pada Mahasiswa STKIP-MB. Konsep yang dihasilkan dala buku ajar digital ini diberi penekanan dengan tulisan berwarna menarik, gambar-gambar yang mendukung materi.

\section{Hasil Tahap Pengembangan}

Tujuan tahap pegembangan adalah untuk menghasilkan buku ajar digital Bahasa Indonesia berbasis HOTS yang valid, praktis dan efektif sehingga layak digunakan dalam proses pembelajaran. Buku ajar digital yang dikembangkan diuji validitasnya sebelum diujicobakan dalam tahap penelitian. Buku ajar ini dinilai menggunakan intrumen validitas yang sudah dirancang berdasarkan kisi-kisi yang telah ditetapkan. Uji validitas dilakukan oleh 2 orang pakar untuk menilai kelayakan produk dari segi isi, kontruksi buku, dan bahasa yang digunakan. Adapun validator yang dilibatkan dalam penelitian ini, yaitu Bapak Aprizan, M.Pd. selaku Dosen STKIP-MB Bidang Ilmu Bahasa Indonesia dan Bapak Radinal Fadli, M.Pd.T. selaku Dosen STKIP-MB Bidang Ilmu Pendidikan Teknologi.

Sebelum melakukan validasi terhadap produk yang telah dirancang, perlu dilakukan validasi terhadap instrumen validitas yang akan digunakan terlebih dahulu. Hal ini bertujuan agar instrumen pengumpulan data tersebut valid dan tepat dalam mengukur kualitas produk. Adapun saran yang diperoleh dari hasil penilaian instrumen validasi dapat dilihat pada Tabel 4.

\section{Tabel 4}

Saran-saran Validator Terhadap Instrumen Validitas

\begin{tabular}{lll}
\hline No & Validasi Pertama & Validasi Kedua \\
\hline 1 & Periksa tanda baca & $\begin{array}{l}\text { Kesalahan penggunaan tanda baca sudah } \\
\text { diperbaiki. }\end{array}$ \\
\hline 2 & Periksa penomoran & Kesalahan penomoran sudah diperbaiki. \\
\hline 3 & Periksa kesalahan pengetikan & Kesalahan pengetikan sudah diperbaiki. \\
\hline 4 & $\begin{array}{l}\text { Kalimat pernyataan lebih } \\
\text { diperjelas lagi }\end{array}$ & Kalimat sudah dibuat lebih jelas lagi. \\
\hline Kesimpulan & Dapat Digunakan \\
\hline
\end{tabular}

Berdasarkan Tabel 4. Menggambarkan bahwa intrumen validitas telah divalidasi oleh validator dengan merevisi intrumen berdasarkan saran-saran dari validator. Setelah dilakukan perbaikan berdasarkan saran-saran tersebut, dilakukan penilaian kembali terhadap instrumen validitas. Kesimpulan yang ditetapkan oleh validator bahwa intrumen validitas penelitian ini dinyatakan valid dan dapat digunakan.

Tahap selanjutnya, yaitu melakukan uji validasi terhadap produk yang telah dirancang. Hal ini bertujuan untuk mengetahui dan menilai kelayakan produk berupa buku ajar digital yang digunakan. Validasi buku ajar dilakukan 2 kali. Secara kuantitatif, validasi pada pertemuan pertama telah menunjukkan hasil yang valid. Namun, validator masih memberikan saran-saran untuk penyempurnaan produk yang dikembangkan. Adapun hasil validasi buku ajar tahap pertama dapat dilihat pada tabel berikut.

Tabel 5

Hasil Validasi Pertemuan Pertama

\begin{tabular}{|c|c|c|c|c|c|}
\hline \multirow[b]{2}{*}{ No } & \multirow[b]{2}{*}{ Aspek yang dinilai } & \multicolumn{2}{|c|}{ Skor } & \multirow[b]{2}{*}{ Jumlah Skor } & \multirow[b]{2}{*}{ Keterangan } \\
\hline & & $\mathrm{V} 1$ & $\mathrm{~V} 2$ & & \\
\hline \multirow[t]{3}{*}{1} & Validitas Isi: & & & & \\
\hline & Cakupan dan akurasi materi & 2 & 2 & 2 & Cukup Valid \\
\hline & Kemutakhiran & 3 & 3 & 3 & Valid \\
\hline
\end{tabular}




\begin{tabular}{|c|c|c|c|c|c|}
\hline & $\begin{array}{l}\text { Pengembangan kecakapan dan } \\
\text { merangsang kemampuan berpikir kritis }\end{array}$ & 3 & 2 & 2,5 & Valid \\
\hline & Rarata Aspek & & & 2,5 & Valid \\
\hline \multirow[t]{5}{*}{2} & Validitas Kontruksi Produk: & & & & \\
\hline & Kelengkapan Kontruksi Buku ajar & 3 & 3 & 3 & Valid \\
\hline & Kemenarikan Penyajian Materi & 2 & 2 & 2 & Cukup Valid \\
\hline & Pendukung Penyajian Materi & 3 & 3 & 3 & Valid \\
\hline & Rarata Aspek & & & 2,7 & Valid \\
\hline \multirow[t]{5}{*}{3} & Validitas Bahasa: & & & & \\
\hline & $\begin{array}{l}\text { Penggunaan simbol, Istilah, dan kata } \\
\text { sesuai PUEBI }\end{array}$ & 4 & 4 & 4 & Sangat Valid \\
\hline & Penyusunan Kalimat & 3 & 4 & 3,5 & Sangat Valid \\
\hline & Rerata Aspek & & & 3,8 & SV \\
\hline & Jumlah Skor & & & 3 & Valid \\
\hline
\end{tabular}

Berdasarkan tabel 5 diperoleh gambaran bahwa validitas isi produk berada pada kategori valid dengan skor 2,5. Selanjutnya, validitas konstruk juga berada pada kategori valid dengan skor 2,7 dan validitas bahasa berada pada kategori sangat valid dengan skor 3,8. Rerata skor validitas pada tahap pertama, yaitu 3 pada kategori valid. Meskipun secara kuantitatif validasi buku ajar tahap pertama telah dinyatakan valid baik dari segi isi, kontruksi, dan bahasa, tetapi tim validator masih memberi saran untuk penyempurnaan buku ajar digital yang dikembangkan.

Berdasarkan saran-saran validator, kekurangan-kekurangan pada buku ajar digital diperbaiki dan dilengkapi. Setelah itu, buku ajar digital divalidasi kembali oleh validator. Adapun hasil validasi kedua dapat dilihat pada tabel berikut.

\section{Tabel 6}

Hasil Validasi Pertemuan Kedua

\begin{tabular}{|c|c|c|c|c|c|}
\hline \multirow[b]{2}{*}{ No } & \multirow[b]{2}{*}{ Aspek yang dinilai } & \multicolumn{2}{|c|}{$\begin{array}{c}\text { Skor } \\
\text { Validasi }\end{array}$} & \multirow{2}{*}{$\begin{array}{l}\text { Jumlah } \\
\text { Skor }\end{array}$} & \multirow[b]{2}{*}{ Keterangan } \\
\hline & & V1 & $\mathrm{V} 2$ & & \\
\hline \multirow[t]{5}{*}{1} & Validitas Isi: & & & & \\
\hline & Cakupan dan akurasi materi & 3 & 4 & 3,5 & Sangat Valid \\
\hline & Kemutakhiran & 3 & 3 & 3 & Valid \\
\hline & $\begin{array}{l}\text { Pengembangan kecakapan dan } \\
\text { merangsang kemampuan berpikir kritis }\end{array}$ & 4 & 3 & 3,5 & Sangat Valid \\
\hline & Rarata Aspek & & & 3,3 & Sangat Valid \\
\hline \multirow[t]{5}{*}{2} & Validitas Kontruksi Produk: & & & & \\
\hline & Kelengkapan Kontruksi Buku ajar & 4 & 3 & 3,5 & Sangat Valid \\
\hline & Kemenarikan Penyajian Materi & 3 & 4 & 3,5 & Sangat Valid \\
\hline & Pendukung Penyajian Materi & 3 & 3 & 3 & Valid \\
\hline & Rarata Aspek & & & 3,3 & Sangat Valid \\
\hline \multirow[t]{5}{*}{3} & Validitas Bahasa: & & & & \\
\hline & $\begin{array}{l}\text { Penggunaan simbol, Istilah, dan kata } \\
\text { sesuai PUEBI }\end{array}$ & 4 & 4 & 4 & Sangat Valid \\
\hline & Penyusunan Kalimat & 3 & 4 & 3,5 & Sangat Valid \\
\hline & Rerata Aspek & & & 3,8 & Sangat Valid \\
\hline & Jumlah Skor & & & 3,5 & Sangat Valid \\
\hline
\end{tabular}

Berdasarkan tabel 6 diperoleh gambaran bahwa validitas isi dan validasi konstruk berada pada kategori sangat valid dengan skor 3,3 dan validitas bahasa juga berada pada kategori sangat valid dengan skor 3,8. Rerata skor validitas pada tahap kedua, yaitu 3,5 pada kategori sangat valid. Validasi tahap kedua ini tim validator 
tidak memberi saran dan telah menyatakan bahwa produk telah buku ajar digital telah dapat digunakan untuk tahap penelitian berikutnya. Adapun rekapitulasi hasil validasi dapat dilihat pada tabel berikut.

\section{Tabel 7}

Rekap Hasil Validasi Produk

\begin{tabular}{rlcccc}
\hline \multirow{2}{*}{ No } & Aspek yang dinilai & \multicolumn{2}{c}{ Rerata Skor } & Jumlah & \\
\cline { 2 - 4 } 1 & Validitas Isi & V1 & V2 & Skor & Keterangan \\
\hline 2 & Validitas Kontruksi Produk & 2,5 & 3,3 & 2,9 & Valid \\
\hline 3 & Validitas Bahasa & 3,8 & 3,3 & 3 & Valid \\
\hline & Total Skor & 3 & 3,5 & 3,8 & Sangat Valid \\
\hline
\end{tabular}

Tabel 7 memperlihatkan hasil validasi buku ajar digital Bahasa Indonesia yang mencakup tiga aspek, yaitu isi, konstruksi, dan bahasa. Ketiga aspek tersebut pada tahap validasi pertama sudah berada pada kategori valid dengan skor 3. Meskipun demikian, buku ajar digital Bahasa Indonesia masih perlu dilakukan beberapa perbaikan. Terdapat beberapa saran validator untuk melengkapi materi buku ajar dan penyajian materi yang lebih menarik. buku ajar digital direvisi kembali sesuai saran validator. Hasil validasi tahap kedua mendapatkan skor 3,5 pada kategori sangat valid. Rerata skor akhir validasi buku ajar digital Bahasa Indonesia memperoleh skor 3,2 pada kategori sangat valid. Berdasarkan penilaian para pakar tersebut, maka buku ajar digital Bahasa Indonesia dinyatakan layak dan dapat digunakan untuk diujicobakan dalam pembelajaran.

\section{Hasil TahapPenyebaran}

Buku ajar digital Bahasa Indonesiadiujicobakab kepada mahasiswa semester I pada perkuliahan Bahasa Indonesia yaitu kelas 1D. Hasil ujicoba terhadap buku ajar digital Bahasa Indonesia tersebut adalah sebagai berikut:

Tabel 8

Hasil Uji Coba

\begin{tabular}{clcc}
\hline No & Aspek yang dinilai & Jumlah Skor & Keterangan \\
\hline 1 & Isi buku ajar & 3,2 & Sangat Valid \\
\hline 2 & Kontruksi Produk & 3,6 & Sangat Valid \\
\hline 3 & Bahasa buku ajar & 3,4 & Sangat Valid \\
\hline & Total Skor & 3,4 & Sangat Valid \\
\hline
\end{tabular}

Hasil uji coba terhadap mahasiswa STKIP Muhammadiyah Bungo memperlihatkan hasil validasi buku ajar digital Bahasa Indonesia yang mencakup tiga aspek, yaitu isi, konstruksi, dan bahasa. Skor yang diperoleh untuk isi buku ajar adalah 3,2 artinya sangat valid, konstruksi produk sebanyak 3,6 artinya sangat valid dan bahasa buku ajar menunjukkan hasil 3,4 artinya sangat valid. Rata-rat hasil uji coba produk terhadap mahasiswa adalah sebesar 3,4 artinya sangat valid.

\section{KESIMPULAN}

Berdasarkan hasil penelitian dapat disimpulkan bahwa 1) Buku ajar Bahasa Indonesia berdasarkan capaian pembelajaran mata kuliah terdiri atas 8 bab yaitu Sejarah dan Perkembangan Bahasa Indonesia, Ragam Bahasa, Kaidah Ejaan PUEBI, Penggunaan Diksi, Kalimat Efektif, Paragraf, Kutipan dan Daftar Pustaka, Karya Tulis Ilmiah. 2) Buku Ajar Digital Bahasa Indonesia berbasis HOTS untuk Mengembangkan Kemampuan Pemecahan Masalah Mahasiswa STKIP Muhammadiyah Muara Bungo (STKIP-MB) valid dan dapat digunakan dalam perkuliahan online bahasa Indonesia. 
4350 Pengembangan Buku Ajar Digital Bahasa Indonesia Berbasis HOTS untuk Meningkatkan Kemampuan Pemecahan Masalah Mahasiswa STKIP Muhammadiyahmuara Bungo - Reni Guswita DOI: https://doi.org/10.31004/basicedu.v5i5.1496

\section{DAFTAR PUSTAKA}

Arnidah, \& Anwar, C. R. (2020). Membangun kemampuan berpikir tingkat tinggi siswa melalui pelatihan soalsoal berbasis HOTS pada guru-guru di Kabupaten Barru. Seminar Nasional Hasil Pengabdian Kepada Masyarakat, 978-982.

Bakri, F., Siahaan, B. Z., \& Permana, A. H. (2016). Rancangan Website Pembelajaran Terintegrasi dengan Modul Digital Fisika Menggunakan 3D PageFlip Professional. Jurnal Penelitian \& Pengembangan Pendidikan Fisika, 2(2), 113. https://doi.org/10.21009/1.02215

Barratt-Pugh, C., \& Rohl, M. (2016). Evaluation of family literacy programs: A case study of better beginnings, a library-initiated family literacy bookgifting program in Western Australia. Library Trends, 65(1), 1939. https://doi.org/10.1353/lib.2016.0019

Desain, P., Materi, P., \& Berita, T. (2019). Mahasiswa Pascasarjana Pendidikan Bahasa Dan Sastra Indonesia UMN Al Washliyah Medan Surel : heriani.spd@gmail.com.1,74-85.

Dinni, H. N. (2018). HOTS ( High Order Thinking Skills ) dan Kaitannya dengan Kemampuan Literasi Matematika. Prisma, 1, 170-176.

Faisal, M., Hotimah, Nurhaedah, AP, N., \& Khaerunnisa. (2020). Peningkatan Kompetensi Guru Sekolah Dasar dalam Mengembangkan Bahan Ajar Digital di Kabupaten Gowa. Jurnal Publikasi Pendidikan, 10(3), 266-270. http://ojs.unm.ac.id/index.php/pubpend

Fuada, S. (2018). Pengembangan Buku Ajar Ips-Sejarah Digital Smp. Jurnal Teknik Informatika, 10(1), 37-48. https://doi.org/10.15408/jti.v10i1.6969

Guswita, R. (2020). Peningkatan Keterampilan Berbicara dengan Menggunakan Model Kooperatif Tipe Think Pair Share di Kelas V Sd Negeri 13 Koto Baru Kecamatan Kubung Kabupaten Solok. Muara Pendidikan Vol.5 No.2, 5(2), 665-673.

Indariani, A., Ayni, N., Pramuditya, S. A., \& Noto, M. S. (2019). Teknologi Buku Digital Matematika dan Penerapan Potensialnya dalam Distance Learning. JNPM (Jurnal Nasional Pendidikan Matematika), 3(1), 1. https://doi.org/10.33603/jnpm.v3i1.1870

Indra Kartika Sari. (2021). Jurnal Basicedu. Jurnal Basicedu, 5(4), 2156-2163.

Lastuti, S. (2018). Pengembangan Bahan Ajar berbasis HOTS untuk Meningkatkan Kemampuan Pemecahan Masalah Matematis Mahasiswa. Kreano: Jurnal Matematika Kreatif-Inovatif, 9(2), 191-197. https://doi.org/10.15294/kreano.v9i2.16341

Mardiana, N. (2017). Peningkatan Physics HOTS Melalui Mobile Learning. Journal of Physics and Science Learning (PASCAL), 1(2), 1-9.

Pinis, E., \& Darmayanti, I. A. M. (2019). Analisis Penggunaan Media Buku Teks Dalam Pembelajaran Bahasa Indonesia Pada Materi Membuat Sinopsis Novel Remaja Indonesia Kelas Viii C Di Smp Negeri 2 Sawan. Jurnal Pendidikan Bahasa Dan Sastra Indonesia Undiksha, 8(2). https://doi.org/10.23887/jjpbs.v8i2.20609

Rabiah, S. (2014). Sastra Dalam Mata Kuliah Bahasa Indonesia Di. Universitas Muslim Indonesia, 1-11.

Saraswati, P. M. S., \& Agustika, G. N. S. (2020). Kemampuan Berpikir Tingkat Tinggi Dalam Menyelesaikan Soal HOTS Mata Pelajaran Matematika. Jurnal Ilmiah Sekolah Dasar, 4(2), 257. https://doi.org/10.23887/jisd.v4i2.25336

Sari, Y., Cahyaningtyas, A. P., Maharani, M. M., Yustiana, S., \& Kusumadewi, R. F. (2019). Meningkatkan kemampuan menyusun soal IPA berorientasi HOTS bagi guru Sekolah Dasar Gugus Pandanaran Dabin IV UPTD Semarang Tengah. Indonesian Journal of Community Services, 1(2), 175. https://doi.org/10.30659/ijocs.1.2.175-183

Sitepu, T., \& Rita. (2017). Bahasa Indonesia Sebagai Media Primerkomunikasi Pembelajaran. Pendidikan Bahasa Dan Sastra Indonesia, 2(1), 67-73. 
4351 Pengembangan Buku Ajar Digital Bahasa Indonesia Berbasis HOTS untuk Meningkatkan Kemampuan Pemecahan Masalah Mahasiswa STKIP Muhammadiyahmuara Bungo - Reni Guswita DOI: https://doi.org/10.31004/basicedu.v5i5.1496

Sugiarto, R., Nurdyansyah, N., \& Rais, P. (2018). Pengembangan Buku Ajar Berbasis Majalah Anak Materi Wudlu Untuk Meningkatkan Pemahaman Siswa. Halaqa: Islamic Education Journal, 2(2), 201-212. https://doi.org/10.21070/halaqa.v2i2.1772

Suwartini, S. (2018). Pengembangan Buku Ajar Pendidikan Karakter Dengan Pendekatan Pembelajaran Berbasis Soft Skill Pada Siswa Sd Kelas II [Development of Character Education Textbooks With Soft Skill-Based Learning Approach for Class II Elementary School Students]. Educhild, 7(2).

Zahroh, S. M., \& Sudira, P. (2014). Pengembangan perangkat pembelajaran keterampilan generik komunikasi negosiasi siswa SMK dengan metode 4-D. Jurnal Pendidikan Vokasi, 4(3).

https://doi.org/10.21831/jpv.v4i3.2561 